\title{
Emblems of Gender Case Study to Indonesian Novel
}

\author{
Asmawati \\ STKIP-YDB Lubuk Alung \\ Asmawatiasmawti715@gmail.com
}

\begin{abstract}
This study aims to describe gender emblems that reflected in Indonesian novel in the time before and after The Indonesian Independence day. There are four gender emblems that reflect in Indonesian novel through socio-literature study and using literature-feminism approach. First, gender banner of novel in 1920s that consist of the desire to reorganize man and woman relationship to create romantic relationship and determine the choice. Second, emblems of gender that contain protest of gender injustice in public appear in 1930s' novels. Third, emblems of gender in 1970s-1990s' novels which contains of gender injustice in local culture (in this case is Java) that placed women as the second social stratum. Fourth, emblems of gender in novel of reformation era voiced global equality for women. The cause of these emblems is the women's education. Having education makes women able togo beyond the tradition, life pressures and self-equality with men in all aspects. These four genders are the basis of women characters in Indonesian novels to do some changes in behavior and place themselves in society and not being tied up in domestic scope anymore. The change of behavior is related with four stigma as the effect of (1) victims of politic, (2) tradition and culture in society,(3) sexual problems, (4) domestic problems. Domestic problem here is not the problem related with family life but as the source that will produce other problems that lead women in wrong position, marginal, hurt, inferior and weak
\end{abstract}

Keywords—Reflection, Gender Emblems, Indonesian Novel

\section{INTRODUCTION}

The focus of this study is the gender emblems that reflected in Indonesian novels. There are some arguments that become the basis of the important of studying gender emblems in Indonesian novels. First, Indonesian has regulated law (UU) No. 7 in 1984 about the deletion of woman discrimination. This ruleis aimed to delete all woman discrimination in Indonesia, because it is not appropriate with Pancasila and 1945 Constitution (UUD 1945). This legalization creates the equality between men and women.

Although the equality has been regulated, in fact women still placed in inferior position. It seems that women's fate is always in marginal position and not many institutions support them. Women always placed unprofitable position and legitimated by tradition, religion and culture. Women also do not have rights to act like what they think, they always been trapped under men's power. Sudamanto (1996:82) states that women were not given freedom to do the things that they want, for example in determining their mate. They must accept the man chosen by parents or other family members to be their husband. Moreover, women are not allowed to get higher education, this caused by the statement that after marriage they will do the housework.

Second, inequity in women has been existed in long time. Their rights are oppressed by the men domination that reconstruct culture and social part, and this placed women in certain stereotype (Susanti, 2998:78 and Nurhaeni, 2009:2). Throughout the history, social justice afflicts women. Women are placed in domestic and reproduction role and it slow their progress. These roles are caused by culture and tradition that create stereotype about women in society. Culture and tradition play important role in making women depend on men. In traditional work division, women are placed in expressive, domestic, reproductive, partial and sensitive part; meanwhile men are placed in instrumental, public, productive, dominant, and competitive. This division will be moved and changed with the raise of new awareness in collective or partial. This condition also raises women awareness to raise and do some changes and reposition the role in all aspects of life as the part of their idealism.

New awareness is the basic of modern society that does not tight up in role limitation but more oriented in life award, freedom, talent, achievement, and individual career as pluralistic society. Each individual, both men and women, has right to enter all life aspects based on his/ her talent and preference. This is one of the gender idealizations that are dream by feminism.

Amir (1976:5) states that principally there is no basic difference between men and women in body function, feels, think, and human nature. The difference is just in sex. Perception that men are more superior in physic and mental cannot fully be accepted because men have more chances to develop their physic and thought than women.

Sex difference is a nature, but the social construction is the statements in society are the cause of distinction throughout the history. Women are also given the potential things that men have so that the equality is a must thing.

Women are not only consider from their beauty, but they also have think, feel to get decision, potential to create masterpiece and work. Both women and men are come from the same source. In reality, strategic sectors need the involvement of women professionally. So that, women and men have the same value that walks together with the development of knowledge and technology and boost up the freedom of historic and cultural load that are endured by women (Sugiharti, 2003: 13-15). 
Third, gender inequality is happened in various forms. Women who are considered as weak, always treated unfair in society. Fakih (2008: 12-13) mentions five manifestations forms of gender inequality; marginalization, subordination, stereotype, women harsh, and double endure. These forms are found in daily life, news, and also mass media.

Gender phenomena are also found in Indonesian literature novels. These phenomena caused a writer actualized the issues happened in social life. These phenomena are combined by writers' imaginations. The novels are the reflection of societies' point of views, thought, arguments, hope and pity.

Based on the problems above, the focus of this research is limited on gender emblems reflected in Indonesian novels. The main problem that wants to answer in this study is how the forms of gender emblems reflected in Indonesian novels are. Literature and feminism theories are used as the basis to find out the gender emblems. As a part of culture, a novel is not only written for esthetic purpose but also as the reflection of economic class structure or material infrastructure like marxis theory. Furthermore, novels also take an important role in getting social function as one of the facilities to construct ideal society (Faruk, 1994). Even thought the society has already known this condition, the fight against value has been already rooted in society.

Gender emblems that are reflected in novels are kind of symbolic fight. This is caused by the writer's reflection in his/ her writing. Damono (1978) explains that literature reflect social issues in society. Novel has function as the media to draws social inequality and also to fight against the inequality. In this study, Indonesian novels that raise gender emblems equality are considered as the symbolic against gender inequality in society.

Gender is a global issue in human right. Study about gender has been a special study about social justice and culture between men and women based on sociology theory. As interdisciplinary study, gender can be related with all aspect in society, one of them is social reflection in literary works. Gender is become one of the important issues in literature. Gender issue is not only a focus in society but also add another color in literature. Gender inequalities are reflected in society. Gender issue can be studied in literature using feminism critics that is formulated in sociology of literature. Junus (1986) states that this approach focuses literature as social document reflected reality in society in certain condition, place and time.

\section{METHOD}

This study used descriptive qualitative method. The object of this study is the emblems of gender that are reflected in Indonesian novels. The data are in soft data. The sources of the data are Indonesian novels published in 1920s till the era after Indonesian Independence Day. There are eight novels that were picked randomly titled Sitti Nurbaya by Marah Rusli; Layar Terkembang by Sutan Takdir Alisyahbana; , Belenggu by Armijn Pane (as the representative of novels before independence day), Sri Sumarah dan Bawuk by Umar Kayam; Pengakuan Pariyem by Linus Suryadi AG, and Ronggeng Dukuh Paruk by Ahmad Tohari (as the representative of novels after independence day); and Saman dan Larung karya Ayu Utami (as the representative of novels in reformation era). The data were analyzed by using details techniques, starting from inventory, classification, formulation, interpretation, discussion, and conclusion.

\section{Gender emblems in Indonesian Novels}

There are four gender emblems in the novels based on the study of action, dialog and thought: (1) gender banner about the desire to reorganize man and woman relationship to create romantic relationship and determine the choice, (2) emblems of gender that contain protest of gender injustice in public, (3) emblems of gender about gender injustice in local culture that placed women as the second social stratum, and (4) emblems of gender that voiced global equality for women. The explanations about each gender banner are as follow.

There are two type of gender emblems in Indonesian novels published before the independence day, (1) gender banner about the desire to reorganize man and woman relationship to create romantic relationship and determine the choice, (2) emblems of gender that contain protest of gender injustice in public activities.

First, the first banner (about the desire to reorganize man and woman relationship to create romantic relationship and determine the choice) can be found in Sitti Nurbaya novel by MarahRusli. This novel reveals problem about tradition against between youth and old people and also discrimination in weak people. These problems relate each other and from the feminism side this problem lead to the problem of gender and also women emancipation.

Although Minangkabau (background of this novel) is matrilineal that give benefit to women, however people still turned blind eyes to them. Women just placed to do the housework (cooking, cleaning, etc), raise children (take care, raise and educate) and take care of the husband. Sugihastuti (2003) states that women activities are just 'dari dapur ke sumur, dari sumur ke kasur' (from the kitchen to the bathroom, from the bathroom to the bedroom) and vice versa. In Minangkabau tradition women activities are famous as the terms mamasak, badan dan, dan baranak (cook, beauty, and have children).In Sitti Nurbaya, women are not allowed to work outside the house. Meanwhile, men are not allowed to get along with women activities and work, because men have works in public sector.

Sitti Nurbaya were the victims of men abuse both inside and outside the house. At house, she must serve the man that she doesn't love, Datuk Maringgih (p. 145). Outside the house, she is also the victims of sexual abuse by crewmen (p. 180-182). Sexual abuse that was done by Datuk Maringgih and his crewmen is the form of men superior power. Soenarjati Djajanegara (1995) in her literature work reflects the opinion about women identity and sexuality are empowered, and bent down. 
If this social reality linked with Goenawan Mohammad opinion (1980) in Seks, Sastra, Kita (sex, literature and us), states that there are three form of attitude in Indonesian novels as follow, (a) literary works that talk about sex, (b) literary works that talks about sex as the part of human natural life and delivered also in natural way and (c) literary works that talks about sex and describe it clearly and fiercely, so that Nurbaya can be categorized into the first form.

So that, through gender banner that consist of the desire to rebuild woman and man relationship to create a harmony and determine the choice is right.

Sitti Nurbaya is a profeminis character that raises the protest about gender injustice in Minangkabau society at that time. Although her feminism was not radical, she was able to raise the spirit of gender for women that experience oppression at the time. The character of Sitti Nurbaya is drawn as the symbol of woman who wants to rebuild the relationship between men and women as the appropriate one, where women have freedom in determining their fate, and husband and also in choosing the work outside the house.

The protest was waved by Sitti Nurbaya after she entered school to avoid tradition of pingit for women in Minangkabau at the time. Minangkabau people have view that women who are enter the school is not agood thing. Nurbaya sees education is good for women because it will develop her knowledge. Her effort was not supported by the situation. Minangkabau people thought that education was useless for women. It can be seen from the students in Nurbaya's school, she is the only Indonesian student and the rest of the students were Dutch.

Pingit tradition also take part in influencing Minangkabau people about women's education. Minangkabau women can enjoy the freedom of just over five years, since they were"maapuih salemo" (remove mucus) until the age of 13 years. When they are approaching 13 years old, women had to be getting ready for the seclusion period. They are no longer move freely, controlled pace, and not allowed to go out of the house if it is not very important. Faced this situation Nurbaya with Siti Maryam (St.Mahmud's wife) hold up the banner of gender protest stating that the educational opportunities not only the monopoly of men, women also have the right to get education. Women who are not getting an education will be the men's game because they do not know what their rights and obligations. Education obtained solely directed women to take care of the household. Thus, their household will be taken care of.

Another reason that consider biological factors as a basis to downplay the significance of socialization for women is because women are considered as second-class citizens. At that time, Minangkabau people did not want women to have equal rights with men. Women were considered weak, in the side of physical, knowledge and reasoning. This is diametrically opposed to the ideology of matrilineal in Minangkabau people. Pennant

Second, gender banner containing the protest against gender inequality in activity in the public sector is reflected in the novel of Sail Sutan Takdir Alisyahbana and Belenggu by Armijn Pane. In the novel titled Layar Terkembang protest was visible from the character named Tuti in voicing behavior of women who tried to align themselves with men in public sector activity, although it is still limited by the hegemony of men. Tuti is shown as an educated female figures (intellect), students who were active in the struggle to liberate women from oppression, keterpasungan, and diversity rights with men. To hoist the banner of protest, Tuti joined any organization or struggles movement of Putri Sedar who try to fight for equal rights between women and men with a variety of activities (p. 137-138). STA succeed to lift woman rightsand raised the banner of gender, which is farsighted. This is also supported by the results of a study conducted by Rampan (1983: 28-29); Damono (in Djajanegera, 2000: xi), and Sugihastuti, 2001: 232). The experts concluded that the character in the novel Sail Tuti expressed as a progressive woman with her way of life that' go beyond the boundaries'in her life.

Progressivity of Tuti's character, similarly, also can be seen from Tini in Belenggu novel by Armijn Pane. If Tuti in Layar Terkembang appeared as a female figure carrying the banner of gender that is still in male-hegemony situation, Tini character in the Belenggu distort the image of women in those days. Tono (her husband) has a lot of activities and work outside the home with his profession as a doctor, Tini was a lot of activity in the social field by leading social organizations (pp. 148-152; 154-156). It was an extraordinary courage of a Armijn Pane at that time. Damono (in Djajanegera, 2000: xi) called Tini and Tuti as the "mighty women", women who were forward-thinking, more advanced than the male around them, who tried to answer the problems that arise and then known as modernization.

Novels titled Belenggu and Layar Terkembang featured female characters who were face and answer the universal problems of human relations in both as citizens and as individuals. They hold up the banner of 'freedom' gender of women from indigenous traditions intervention, religious, moral, and other cultural conventions. The female figures appear as whole human person according to their human existence without losing their nature as women and to choose and do something that they like. Thus, female figures in these novels were unconventional in the era. In fact, the public were not ready yet to acceptwomen leaders with that personal 'identity'.

Third, gender banner containing claims and lawsuits against the gender gap in the local culture that places women as second-class human beings. This phenomenon was reflected in Sri Sumarah and Bawuk novel by Umar Kayam; Pengakuan Pariyem by Linus Suryadi AG, and Ronggeng Dukuh Paruk by Ahmad Tohari. In the novel titled Sri Sumarah for example, is an obedient female character and faithful to her husband (the late husband), patient, paced resigned over what happens within her. However, finally Sri did 'protest' against the establishment of moral and ethical toward women-especially the moral and social 
culture of Javanese society at that time - when she meta young man customer. A young handsome man, has strong body, wellmannered, has undermined her defenses as true Javanese woman (pp. 95-100).

As a Javanese woman, Sri, whowas initially has character as a true Javanese women, finally did a 'protest'; 'against' and 'crashing' fences customs and ethics of Javanese women that full of philosophy and life. Here, Kayam was successto show Java female character who eventually see the fact that she was not able to resist the call of the heart and the sounds of nature as human, although she must be against Javanese ethics and customs, especially religion. She 'surrendered' to the handsome and passionate young man.

The same situation was also experienced by the novel character named Iyem in Pengakuan Pariyem by Linus Surya AG. In this novel, Iyem, was shown as a female housekeeper that has true Javanese women personality in Kanjeng Cokro Sentono noble family in nDalem Suryomentaraman Ngayogyakarto. She was portrayed as an innocent women, less educated, modest, obedient, loyal devoted, but has a personality that is interesting precisely because of her innocence. Because of her plump body and attractive face, she resigned to the will of Den Baguse, the eldest son of the family who are always seduce her and even have sex with her (pp. 135-139). She volunteered to serve Den Baguse passion and she enjoyed it. However, sometimes she who took the initiative to tempt Baguse Den first (pp. 140-143).

Behind Iyem submission and willingness to Den Baguse, actually Iyem who were seemingly helpless 'rebel' establishment of tradition customs and ethics. Iyem, with influence and support of her boyfriend Sokidi Kliwon,who has brought the metropolitan, life as a woman who dared to go against the flow Javanese customs and traditions of its people. In fact, Iyem is a symbol of innocent Javanese women and uneducated but have enough experience 'advanced' in terms of sex and able to 'conquer' Den Baguse (p. 76-78).

Besides, as a naive and uneducated housekeeper, Iyem also described as a woman who is already good in sex. This is one form of protest to 'make fun' and 'pouting' the nobles who considered aswomanizer, (pp. 136-138). Iyem figures cynically 'sue' and overturns the values of family honor noble (Ngayogyakarta etc.) that should be regarded as respectable gentry, including the moral and immoral (sex).

Iyem also did 'protest' toward Den Baguse by giving her 'virginity' first to Mas Sokidi Kliwon, herboyfriend, before Den Baguse (pp. 65-70). It can be seen as a form of Iyem"rebellion" against the male-hegemony.

The same story is also reflected in the novel Ronggeng DukuhParuk by Ahmad Tohari. A trilogy novel RonggengDukuh Paruk (Note for Mother, Lintang Kemukus Dini Hari dan Jantera Bianglala) was also sued in a culture of gender bias in her womanhood local culture. If the figures Iyem give her 'virginity' to Kliwon her boyfriend, then Srintil give her 'virginity' to Rasus her boyfriend, the man she loves, before Srintil must follow the ceremony 'Bukak klambu' (open mosquito nets). It is a ritual ceremony to auction off the 'virginity' of the candidate of ronggeng (Srintil) with a sum of money and to establish herself as a ronggeng.

As ronggeng, character of Srintil is shown as a woman who dare to rebel against the traditions of the world ronggeng Paruk Hamlet. Although the tradition, a ronggeng not justified bind themselves to a man, Srintil cannot forget Rasus, his beloved hero. When Rasus disappeared from Dukuh Paruk, Srintil was hurt. Srintil can not accept this situation and rebelled in her own way. She was brave and bold step over provisions that have long been entrenched in the world of Peronggengan, especially in the relationship between a ronggeng with the leader. Srintil sometimes dare to refuse orders of leader. Srintil appeared as a symbol of rebellion tradition, namely relations with ronggeng's leader.

At the age of twenty, Srintil self-genuineness start firm. She was dignified, not hungry like most people in DukuhParuk, and rejected of men that she did not like. This is something beyond the world of Peronggengan tradition, because tradition looked ronggeng as 'belonging together' whoever able to afford it. Here's the problem against in the novel trilogy Srintil RonggengDukuh Paruk. A banner containing the sound of feminine gender is so brave on the environment at the time.

Both characeters of Sri in Sri Sumarah, Iyem in PariyemDunia Batin Seorang Wanita Jawa and Srintil Woman in Ronggeng Dukuh Paruk, all of them carry the banner of gender. They fly the banner of gender in subtle, cynical, and ironic, but sharp way.

Fourth, gender bannerthat voiced the global womanhood discrimination deconstructamong women and men. This reality is found in the dwilogi novel of Ayu Utami, titledSaman (1998) and Larung (2001). In Saman Ayu Utami outspoken protest discriminative treatment of women both in terms of men and women as well as in regard to sexthroughher characters such as jasmine, Cok, Sakuntala, and Laila. She protested against the stereotypes that place women as subordinate males, as illustrated in the following quote.

My body dance. Dance is the endless exploration with my skin and bones, I feel soreness, pain, palpitation, and comfortable too. And the death.my body dance. It obeys passion not lust. Sublimate. Libinal. Labyrinth (Saman, pp. 115-116)

Here, in this city, he ties me in the bed at night and gives me my first two lessons about love. This is his advice. First, man approaches woman. Woman who is approach man must be a bitch. Woman will give her body to an appropriate man and tied by marriage. Later, when I grown up, I will say it as hypocritical prostitution (Saman, pp. 120-121) 
At the end of the novel Ayu Utami's Saman describes how women can also do something which has always been associated as a male behavior.

Yasmin in a letter e-mail to Saman said

Saman, do you know, the night that I remember was when I touch your body and enjoy your body when ejaculation. I want to come. I teach you. I rape you (Saman, pp. 169)).

Ayu is shown protest loudly as she felt annoyed at the women had only made asthe object. Character of Cok is calledas the slut (female experiments) are always have many boyfriends and disappoint them Ayu said:

sometimes, I feel upset, no matter what we do, which is also done by men, which is why we called as bad women. When men take turns sleeping with lots of girlswill be branded as hero, Arjuna. But the women who slept with many men will be called as whore. Whatever we do, we always considered as an object. Even by our fellow (Larung, pp.83-84)

Compared with previous Indonesian novels, novels Saman and Larung can be said to be different once the show bias of gender, breaking the dominance of men over women. In fact it can be said that the two novels is the most daring first novel in the tradition of breaking Indonesian womanhood and sue outspoken of bias gender. In fact, Saman and Larung may not be an exaggeration to say also break the storytelling so straightforward, open, and clear, without any loss of 'womanhood'. This is perhaps called as the deconstruction and reconstruction done at the same time toward the author of the feminine in the global era. Women in global era show freedom in voicing the aspirations and desires as well as express the thrill of the most fundamental human side, though sometimes feels 'excessive' or 'through the boundaries of ethics' for the guard ethics and culture, especially religious values. Global feminism nuance was once dominated the second story of this novel. It is precisely through the female characters; Cok, Sakuntala, Yasmin, and Laila, who have been the subject of sex in society "as if" became a taboo to be discussed openly, in Larung it is freely discussed, clear, and straightforward, without impressing the nudity with extraordinary exploits of captivate languages.

\section{DISCUSSION}

Based on the banner of gender that are reflected in the Indonesian novels above, it is clear that since 1920's until the era of reformation, social injustice issues are commonly affecting women. Women positioned solely on domestic and reproductive roles greatly impede their progress in the public and cultivate the production. It is an engineering culture and traditions that create specific labeling or stereotyping of women who have deep roots in the community. Culture and tradition play an important role in shaping stereotypes that create dependency of women on men is quite large. To reposition the role of women in social interaction, the concept reconstruct gender was born to reconstruct relations of men and women universally to open the same opportunity to cultivate the various aspects of life without being influenced by gender differences.

In the traditional division of work, women are placed on the role of expressive, domestic, reproductive, partial, and sensitive part, while the men placed on the instrumental role, the public, productive, dominant, and competitive part. This division of work will shift and change direction with the emergence of a new consciousness, both as opening up horizons of female characters in the novel Indonesia to hoist the banner of gender is essentially due to the influence of education obtained by the women themselves. In the novels of Indonesia before independence dayare told that in order to be able to take education, a woman has to deal with two things, the pingitan tradition and limited schools to accept women for the study. Pingitan is a tradition that was encountered in the Minangkabau and Java for example, requires a 12-year-old daughter had to stay at home, to get his soul mate. As suggested by the book Sitisoemandari Soeroto Kartini Sebuah Biografi (2001:4) that the Dutch colonial period the customs prevailing among the feudal nobility and the upper middle-called seclusion. About the meaning of this seclusion ever put forward by de-Stuers, who examined the women's movement in Indonesia, which was later published in the book Sejarah Perempuan Indonesia: Gerakan dan Pencapaian (2008). He said the pingitan (seclusion) is taken from the word "horse of seclusion" which means horses are confined in cages and not allowed to roam freely like other horses. The metaphor is acceptable because of the association between the meaning of the horse is not allowed out of the cage, with a woman who does not allowed to go out of their home.

The overview of the tradition of seclusion for girls, in Java for example also appears on Kartini's letters (Door Duisternis tot Licht/ Habis Gelap Terbitlah Terang, J.H. Abendanon, 1979), which reflects the society in his day. In one of the letters of Kartini:

When a girl age 12 and a half, it is the time for her to leave her childhood. She should say goodbye to her school friends. She is considered as grown up lady and should life in the house until a man comes to marry her and take her home.

(Letter of Kartini to Mrs. RM-MadriAbendanon-Madri, Sulastin-Sutrisno, 1979:50-51) 
Since that timea new awareness raise to women who are no longer bound within the limits of the role, but is more oriented to the award of life, liberty, talents, accomplishments, and individual careers as basic pluralistic society. Each individual both men and women have the right to enter various fields of life according to talent and pereferensinya respectively. It is one of the idealization of the aspired gender advocates of gender and feminism movement figures.

In the feminist perspective raising the banner of gender by female figures novels Indonesia indicated the symbolic form of resistance against domination of men who regard women as domestic creatures, which is constructed as a housewife. Inclusion of female characters (Sitti Nurbaya, Tuti, and Tini) to schools and the public arena, both as women's work and social activist organizations have demonstrated their ideas about gender equality and reject the notion that the presence of women was in grade two (the second class), liyan (the other), or marginalized (de Beauvoir, 2003: $\mathrm{x}$-xi). What's interesting about the novels studied is that the resistance to the hegemony of patriarchy is not only imaged on the novels written by women, but also written by male novelists. That is, awareness of gender inequality in the Indonesian community has become the literary anxiety, as one part of the intelligentsia, and has been plaguing him for desire to arise. Patriarchal hegemony that confine women at home and restrict motion and denied a voice, it was disturbing the tranquility of the writers, so they criticize the work of writing a novel that elevates the idea of the importance of education for women and the role of women in the public sphere, so it will slowly achieved equality gender in society as a collectivity or partially.

In relation to sex, it seems that the banner was unfurled gender female characters in the novels of Indonesia showed three patterns, as Mohammad (1980) told in his book Seks, Sastra, Kita. He suggests that there are three patterns of attitudes of Indonesian novels on this issue and how sex described. First, try to discuss about sex, but not clearly and dare. This can be found in woman characters in novels before Independence Day. Second, sex is discussed as part of a human normal life and described it fairly well, as reflected in the behavior of Sri, Iyem, and Srintil. It also proves that the gender banner novels after independence talks about sex fairly and humanely as a form of resistance to the curb where the tradition of women. Third, literary works that talks about sex and describe it clearly and fiercely as described in Ayu Utami's novels.

Sex and sexual activity in view of the banner of gender, is something that is innate for humans, something that is attached to the biological facts. According to Faruk (2011) as part of the biological facts, sex is very individual. However, sexual activity often contain very basic social functions. First, only through sexual activity human being can survive: sex is a precondition for the reproduction of the human race. Based on the reproductive demands, sexual activity can not be taken place on an individual basis: humans need other people in different genders. In such a case, sex becomes a social activity, not the activity of individual.

Moreover, Faruk (2011) states that because of its social function, each community has an interest in sex and sexual intercourse. Communities trying to regulate and direct the sexual activity that does not move in the direction of their individual functions alone, so the continued existence of the community can be nurtured and maintained. Individuals are encouraged to get to know, believe, and love the diversity of gender, to get to know, trust, and like the inevitability of intercourse between different sex, and also to get to know, believe, and love must carry on relations between the sexes and keeping the sexual health.

The statements above do not mean naturally and biologically of sexual activity is disappeared. The function is still exist but it is kept in human private area. The function will appear if the social and cultural crisis happened. The crisis can be happened when the control of sexual activity is not achieving the goal of society anymore. Moreover, the crisis also may happen if human find new way to do their individual sexual activity maximally without losing their social function. This is what Ayu tells in her novels through her characters.

\section{CONCLUSION}

Based on the analysis and discussion above it can be conclude that emblems of gender that are reflected in Indonesian novels can be classified into four types; (1) gender banner about the desire to reorganize man and woman relationship to create romantic relationship and determine the choice, (2) emblems of gender that contain protest of gender injustice in public, (3) emblems of gender contains of gender injustice in local culture (in this case is Java) that placed women as the second social stratum, and (4) emblems of gender in novel of reformation era voiced global equality for women

These four genders are the basis of women characters in Indonesian novels to do some changes in behavior and place themselves in society and not being tied up in domestic scope anymore. The change of behavior is related with four stigma as the effect of (1) victims of politic, (2) tradition and culture in society,(3) sexual problems, (4) domestic problems. Domestic problem here is not the problem related with family life but as the source that will produce other problems that lead women in wrong position, marginal, hurt, inferior and weak. Good luck young Kartini. Ibu Pertiwi is waited for your effort.

\section{References}

Abendanon, J.H. (1979). Door duisternis totlicht. Edisi Bahasa Indonesia diterjemahkan oleh Sulastin Sutrisna dengan judul Habis Gelap Terbitlah Terang. Jakarta: Djambatan

Alisyahbana, St. Takdir. (1975). Layar terkembang. Jakarta: Balai Pustaka

Amin, Samir. (1976). Unequal development. New York: Monthly ReviewPress 
Beauvoir, Simone de. (2003). Second sex: fakta dan mitos. Edisi Bahasa Indonesia diterjemahkan oleh Toni B. Febriantono. Surabaya: Pustaka Promothea.

Djajanegara, Soenarjati. ( 2000). Kritiksastra feminisme, SebuahPengantar. Jakarta: Gramedia.

Djajanegara, Soenarjati. (1995). Citra wanita dalam lima novel terbaik sinclair lewis dan gerakan wanita di amerika. Depok: FakultasSastraUniversitas Indonesia

De Stuers, CoraVreede, (2008). Sejarah perempuan indonesia: gerakan dan pencapaian. Jakarta: Komunitas Bambu.

Fakih, Mansour. (2008). Analisis gender dan transformasi sosial. Yogyakarta:Pustaka Pelajar.

Faruk, HT.(1994). Pengantar sosiologi sastra: dari strukturalisme genetik sampai postmodernisme. Yogyakarta: Pustaka Pelajar

Faruk, HT. (2011). "Seks kontekstual dalam sastra indonesia" dalam jurunal kajian sastra jentera. Jakarta: Badan Pembinaan dan Pengembangan Bahasa Kemendikbud

Mohamad, Goenawan. (1980). Seks, sastra, kita. Jakarta: Sinar Harapan

Junus, Umar. (1986). Sosiologi sastra: persoalan teori dan metode. Kuala Lumpur: Dewan Bahasa dan Pustaka Kementerian Pelajaran Malaysia.

Kayam, Umar. (1975). Sri sumarah. Jakarta: Pustaka Jaya

Nurhaeni, Ismi Dwi Astuti.(2009). Kebijakan publik pro gender. Surakarta: Universitas Sebelas Maret.

Pane, Armijn. (1982). Belenggu. Jakarta: PT Dian Rakyat.

Rusli, Marah. (2002). Sitti nurbaya: kasih tak sampai. Cetakan ke-37. Jakarta: Balai Pustaka

Soeroto, Sitisoemandari. (2001). Kartini sebuah biografi. Cetakan ke-6. Jakarta: Djambatan.

Sudarmanto, Y.B. (1996). Jejak-jejak pahlawan: dari sultan agung hingga syekh yusuf. Jakarta: Grasindo

Sugiarti, dkk. (2003). Pembangunan dalam perspektif gender. Malang:Universitas Muhammadiyah Malang.

Suryadi AG, Linus.(1981). Pengakuan pariyem dunia batin seorang wanita jawa. Jakarta: Sinar Harapan.

Susanti, Emy. (1998). "Menggugat bias jender dalam logika pembangunan" dalam Ibrahim, Idi Subandy dan Hanif Suranto (ed). Wanita dan media: konstruksi ideologi jender dalam ruang publik orde baru. Jakarta: Rosda.

Tohari, Ahmad. (2003). Ronggeng dukuh paruk (Edisi Revisi). Jakarta: PT Gramedia

Utami, Ayu. (1998). Saman. Jakarta: Kepustakaan Populer Gramedia.

Utami, Ayu. (2001). Larung. Jakarta: Kepustakaan Populer Gramedia 